\title{
Examination About the Law Enforcement Strategies which are Influence the Criminal Behaviour
}

\author{
Csaba SZABÓ ${ }^{1}$
}

\begin{abstract}
This study intends to react to challenges threatening Europe's internal security. The perception of security of Europe's citizens has deteriorated due to recent terrorist attacks. The internal security strategies of Europe's countries should be revised because it is impossible to predict which European country will suffer another terrorist attack. Prevention can be classified as the most important strategy in this situation. The deplorable terrorist attacks that occurred in France and Belgium have shown that in addition to the civilian population, members of the police are also exposed to attacks of terrorists. The study analyses the comprehensive theoretical approach, which is a research starter to help the law enforcement agencies in creating a more coherent and effective concept for preventing and uncovering crimes in order to protect, firstly, the civilian population and, secondly, policemen. Hypotheses are formulated, which examine basic elements of the strategies for preventing and uncovering crimes from the viewpoint of the organizational culture of the police.
\end{abstract}

Keywords: terrorism, crime prevention, uncovering crimes, police, public safety

\section{Introduction}

Experts engaged in research work in the field of police sciences have a uniform and unbroken opinion that the more police we have in a given country, the more effective indicators can be achieved in the field of crime prevention and detection. ${ }^{2}$ The reduction in crime is one of the primary goals of any government. This is understandable, since the efficient management of activities of public authorities responsible for public security and the appropriate use of available tools can significantly improve citizens’ perception of security.

The possibility of practical realization of criminal intent can primarily be suppressed by the crime prevention strategy of the police. The strategy shall define the effective use of police forces and tools, and the timeline for implementation of the formulated specific goals and objectives. ${ }^{3}$ Both personal and material conditions of the police exceed the expectations of the age. Programmes of law enforcement training incorporate case studies and relevant

1 Ph.D., Pol. Maj., National University of Public Service; e-mail: szabo.csaba@uni-nke.hu

2 Social scientists often argue that increasing the number of the police can make only minimal contributions to a positive move in indicators of crime detection and crime prevention. In their view, the extension of the social institution network and the strengthening of the stability of family relationships, as well as the successful solution of labour market challenges are increasingly able to contribute to the management of criminal inclinations of the society.

3 The spatial and temporal analysis of frequency and intensity of crimes is the cornerstone in the development of crime prevention strategies. 
aspects of changes in legislation. Policemen are trained for management of unforeseen situations by psychological, educational and communication methods. Nevertheless, the efforts of the police were not providing adequate answers to the challenges of policing, and in some European countries the deterioration of public security can be observed.

\section{Investigation of crime prevention and crime uncovering concept of law en- forcement agencies.}

The permeability of free borders in Europe is one of the most vulnerable points from the viewpoint of public security. Effective strategies for internal security, crime prevention and uncovering are a tool to combat unexpected crimes causing fear to all societies. However, to effect the desired results, the implementation of the strategy for public security shall not be restricted exclusively to the territory of one particular country and, primarily a system-level public security strategy shall be devised.

The types of crime, to which European societies are most vulnerable, include terrorist offenses, homicides, assaults, robberies and car thefts. The police can effectively reduce the number of these particular crimes provided certain work methods work properly under certain circumstances.

Policing and criminological research, being so far completed or pending, primarily addresses criminal intents of juveniles, criminological aspects of crime scenes, the risks of globalized crime, issues of power structure in the state, as well as the causes and consequences of economic crime. These studies are increasingly complemented by analyses of terrorist offenses planned or carried out in the European continent and the exploration of their causal factors. The patterns of the research provide answers to the many arising issues ${ }^{4}$ and aim to achieve a result-oriented crime prevention concept with success rates that may not be always measurable in concrete figures. ${ }^{5}$ If we accept the paradigm that the work of the law enforcement has impact on the criminal behaviour, we need to continue further research on the effects of law enforcement on crime and the causal context thereof. ${ }^{6}$

Along with ongoing changes in criminal behaviour (age peculiarities, upgrading of means, criminal networks), the law enforcement bodies have been also constrained to revise their methods of preventing and uncovering crimes.

In order to define the area for further research, the hypotheses, which point out the shortcomings of the internal security strategies and may induce changes in the development of the police strategy for crime prevention and uncovering crimes, are specified in eight items.

\section{The more police we have, the less crime there will be.}

Governments make proposals to increase the police force when this is justified by the social expectations and the increase in the offense number. [1] The increase in the number of police also increases the police presence, however the public perception of security does not always show positive correlation. Research has shown that the increase in police presence causes the

4 For example, personal and social causes of the development of criminal behaviour, the consequences of existential despair's crime-driving force, or definitions of the system of crime commitment.

5 Such results are the specific and purposeful use and integration of police resources, the dissociated detection of certain offenses causing social discontent, and the exploration and localisation of illegal activity spots directly threatening public security.

6 Herman Goldstein [12] conducted research and formulated new paradigms for the components affecting law enforcement and the direct effects of policing strategies on criminal behaviour. 
transfer of criminal operations to an area less "infected" from the police point of view. [2] In terms the research effectiveness, issues shall be formulated with regard to the variables of criminal infectedness in the examined area, the evolution of types of the crimes committed and the correlation tests. The answers shall be examined in different social environments and the results shall be analysed to determine whether there is a correlation between the police numbers and the trends in crime rates. [3]

\section{The shorter the time between a crime and the police arrival at the crime scene, the less crime will be in the examined area.}

In analysing the hypothesis, we can conclude that the reduction in the police response time leads to relatively more arrests since offenders have much less time to leave the crime scene. ${ }^{7}$ The establishment of uniform emergency call centres deemed to be the jewel of police development helps to reduce the response time of the police. The police response time is significantly influenced by location of crime victims in relation to the nearest police patrols. ${ }^{8}$ The issues whether the trends in police response time are in correlation with the number of police patrols and the police excessive workload require further investigation. [4]

\section{Determining random police patrol routes can greatly contribute to keeping potential offenders away from the public space.}

Increasing the safety of public areas is considered an extremely important task. The number of crimes committed in public areas is affected by a combination of factors. ${ }^{9}$ Randomly selected police patrol routes cover those public areas (parks, squares, bus and train stations, airports) where larger numbers of people occur. In the initial phase of research those factors influencing the development of crimes shall be examined, which point to the displacement of activity areas of offenders driven out from more populous public areas. This is understandable given that the randomness of police patrol routes should be decided taking into account the location of criminally infected areas. [5]

Research has shown that after the provision of directed patrol some police organizations analyse and assess data originated in relation to criminally infected areas and define the next patrol route based on those. [14] [15]

7 The area of forensic science also deals with the social phenomenon, which focuses on the adoption of effective crime prevention strategy and not on statistical indicators of crime uncovering. [12] [13] In the context of social support of the police, an important aspect is how society accepts the view that intelligence is able to contribute to prevention. Crimes destroy the society's perception of security, thereby the value of operability of crime prevention strategies increases.

8 The time of arrival of the police patrol to the scene is significantly affected by the distance to the crime scene, weather conditions, traffic density, accessibility of the crime scene, the accuracy of description of the situation and/or location given by a person reporting the crime.

9 Such contributing factors are: the efficiency of public lighting, the density of surveillance camera locations and the number of police hours spent in public areas. 
The more patrol presence is concentrated at the criminally infected areas, the less crime there will be.

Researchers have different opinions on the significance of the increase in police presence and its usefulness in uncovering crimes and crime prevention. Many knowledgeable researchers have a unanimous opinion that, as the first step, the solution shall be found for negative processes taking place in the society and only after this examine whether there is still a need for increasing the police presence in criminally infected areas. [6] Those arguing against the increase in police presence explain that, as the first step, homelessness, social justice, economic inequality and social phenomenon of racism should be addressed.

\section{The more arrests of offenders representing high risks the police make, the} less serious and violent crime there will be.

The increase in the number of arrests made by the police cannot be clearly linked to the reduction in the number of crimes. The processes should be studied, the results of which may contribute to the decrease in the number of very serious crimes. Fundamental issues should be formulated to develop preventive solutions to curb the criminal intent. The extent shall be determined, to which arrests initiated by the police can contribute to the suppression of armed and committed in group crimes that involve taking of human life. There are two possible ways I wish to show, with which, through their integration in the police methodology statistically measurable results can be achieved in the reduction of serious crimes.

Retention: it should be formulated as a question, whether the detention of persons, who have committed criminal offenses can serve as a deterrent for those intended to commit crimes. Research has shown that the higher the detection ratio is in relation to the particular crime, the less crimes of this type there are. [16] [17] The answer can be found in effectiveness, decisiveness, strategy, responsiveness and social support of the police.

Special prevention: it can be assumed that people who have already committed offenses and were arrested by the police - because of heavier sentences foreseen by the law - will not become re-offenders, as opposed to individuals who after committing an offense were not yet arrested and put in detention by the police. ${ }^{10}$ The special prevention focuses on the value of freedom deprivation.

\section{Community Policing strengthens trust between the police and the citizens, reducing the number of crimes committed.}

Resulting from the research carried out so far, [18] [19] community policing aims to create an effective dialogue between the police and the citizens. The concept essentially consists of the coordinated cooperation between citizens, non-governmental organisations, business groups and the law enforcement agencies, which may facilitate the development and implementation of an effective strategy for crime prevention and uncovering. [7] This strategy leads to a complex problem-solving approach that can facilitate communication between the police and civilians (individuals and organisations). The efficient operation of the community policing model studied from the viewpoint of crime prevention and uncovering must meet a number of conditions.

10 When studying the special prevention, we found a relationship between the number of arrests initiated by the police and the size of sentences decided by the court. Repeated offenses are actions based on individual decisions, however the authorities must demonstrate that these actions are not profitable because of the severity of punishment. 
These conditions include:

- Social stability and community cohesion. ${ }^{11}$

- Proper motivation and moral behaviour - modes of behaviour - within the police force. ${ }^{12}$

- Public confidence in the police. ${ }^{13}$

- Commitment to changes at political, economic and professional levels. ${ }^{14}$

- Providing sufficient resources required for the change. ${ }^{15}$

- Strong community and non-governmental organisations. ${ }^{16}$

Community policing as a new reform effort is clearly in the interests of citizens and: consequently, strengthens police communications strategy.

The more policemen have the ability to detect and identify characteristic and direct root cause components of crimes, the more effectively can public security be strengthened.

The gist of Problem-Oriented Policing [11] is to ensure that police patrols and investigators, for the effective investigation, focus on the original proximate causes of crimes. The police will consider innovative solutions and involve neighbouring scientific areas to successfully complete the stuck investigations. The police are trying to build a much closer relationship with the public, thereby the citizens can ascertain that the police are serious about dealing with their problems. [8]

The problem-oriented strategy consists of four parts: mapping, analysis, response and assessment.

The police structure currently used is based on the case-based policing method. ${ }^{17}$ The determination of the necessary tasks shall be started with the systematic mapping of information available on crimes. With the new results thus obtained, direct connection points will be laid down regarding the causes of crime. The strengthened abilities of the police in identifying causal relationships will lead to more successful crime uncovering.

11 The condition of social stability and community cohesion is the development of an approach to be, to a certain degree, politically constant. It is difficult to fill the communication of the police with positive content if a given State uses the police for achieving its own objectives in politics.

12 Corrupt behaviour can more likely develop in police forces with low-paid staff with a low morality level.

13 Helpfulness, straightforward and honest dialogue, and corruption-free behaviour on the part of the police staff are prerequisites for confidence expected from the public. One of the basic conditions for the effective functioning of community policing is the cooperation between the police and civilians be based on unconditional trust.

14 A clear commitment is required on the part of the governmental decision makers to promote reform processes necessary for the development of community policing. These processes can increase the effectiveness of the measures and the police accountability, while making decisive steps forward in the area of such issues as corruption, excessive use of police force, or the violation of human rights.

15 The reform efforts require significant financial investment to establish new police agencies, purchase new equipment, as well as provide support for the implementation of new projects.

16 The strategy related to the community law enforcement can only be achieved if the community organisations cooperate with the police.

17 Case-based policing methods are: response to events, information collection, analysis and evaluation of available data. 


\section{Detection of illegal corruption offenses within the police can promote - at the individual and community levels - the formation of law-abiding behaviour.}

Unlawful action of people is judged by the judicial authorities on the basis of sanctions regulated by the law and defined in the norms. Based on compliance with norms and reciprocity, people have a right to expect that members of the police provide corruption-free service. [9] The normative compliance is required by the law from all public officials, including the police. Enforcement of law-abiding conduct is a legitimate tool of accountability in the hands of the police and, as a result, the fight going on to uncover corruption offences within the police is positively perceived by the members of society.

\section{Conclusions}

By means of analysing and studying the scientific hypotheses, the basics of a comprehensive crime prevention model can be created that can assist in devising a unified security strategy. This security strategy shall be based on the alliance of the police and people committed to law-abiding behaviour. After serious terrorist offences of the last period causing a number of deaths, the people of Europe have expressed fear. Opinion polls confirm that people feel the need for stronger, more efficient and more decisive police. [10] The development of the analysed hypotheses within a research team will enable us to strengthen the public security in Europe.

The effectiveness of police can primarily be strengthened by the flow of intelligence from citizens to police, strengthening of the confidence index of the police and the citizens, and increasing the presence in public areas. [11] We have to keep the security of the EU's external border sections on the agenda, but we should not forget about such internal challenges as illegal migration, terrorism, organised crime, economic problems, unstable states, and infectious diseases.

\section{References}

[1] VOLLAARD, B., KONING, P.: The Effect of Police on Crime, Disorder and Victim Precaution. Evidence from a Dutch victimisation survey. International Review of Law and Economics, 29 (2009), 336-348. DOI: https://doi.org/10.1016/j.irle.2009.03.003

[2] BRADFORD, B.: Police numbers and crime rates - a rapid evidence review. Her Majesty's Inspectorate of Constabulary. London, 2011. www.justiceinspectorates.gov.uk/hmic/media/ police-numbers-and-crime-rates-rapid-evidence-review-20110721.pdf (Downloaded: 109 2015)

[3] LEVITT, S. D.: Using Electoral Cycles in Police Hiring to Estimate the Effect of Police on Crime: Reply. The American Economic Review, 92 (2002), 1244-1250. DOI: https:// doi.org/10.1257/00028280260344777

[4] BOWEN, A.: Police response time to emergency calls slows. Inching up response times. Metro, 1712 (2014).

[5] RONALD, V. C.: Improving Street Lighting to Reduce Crime in Residential Areas. Problem-Oriented Guides for Police. Response Guides Series, 8 (2008), 3-8. 
[6] More Policing Does Matter - Recent Findings from Objective Empirical Research. www. majorcitieschiefs.com/pdf/news/more_policing_does_matter.pdf (Downloaded: 222 2015)

[7] CASEY, J.: Implementing Community Policing in Different Countries and Cultures. Pakistan Journal of Criminology, 4 (2010), 55-70.

[8] SPELMAN, W., ECK, E. J.: Problem-Oriented Policing. National Institute of Justice, 1 (2008), 2-4.

[9] TYLER, T., LEVI, M.: The Reasons for Compliance with Law. Paper for the Workshop on the Rule of Law, (2008), 2-5.

[10] CASERT, R., CHARLTON, A.: Europe anti-terror raids net dozens amid high anxiety. The New York Times, 161 (2015), 6.

[11] MOORE, M. H.: Problem-Solving and Community Policing. In. TONRY, M., MORRIS, N. (Eds.): Modern Policing. Crime and Justice: A Review of Research. Vol. 15. Chicago: University of Chicago Press, 1992. DOI: https://doi.org/10.1086/449194

[12] GOLDSTEIN, H.: Problem-Oriented Policing. New York: McGraw-Hill, Inc., 1990.

[13] CLAWSON, C., CHANG, S. K.: The relationship of response delays and arrest rates. Journal of Police Science and Administration, 5 (1977), 53-58.

[14] BECKER, S. G.: Crime and Punishment: An Economic Approach. University of Chicago and National Bureau of Economic Research, 762 (1968), 169-217. DOI: https:// doi.org/10.1086/259394

[15] BECKER, S. G.: Altruism in the Family and Selfishness in the Market Place. Economica, New Series 48189 (1981), 1-15. DOI: https://doi.org/10.2307/2552939

[16] LOGAN, G. D.: Attention and Automaticity in Stroop and Priming Tasks: Theory and Data. In. Cognitive Psychology 12. 540-543. Toronto: University of Toronto, Erindale College, 1975. DOI: https://doi.org/10.1016/0010-0285(80)90019-5

[17] GREENBERG, D. F., KESSLER, R. C.: The Effect of Arrests on Crime: A Multivariate Panel Analysis. Social Forces, 603 (1982), 771-790. DOI: https://doi.org/10.1093/ sf/60.3.771

[18] SEGRAVE, M., RATCLIFFE, J.: Community Policing: A descriptive overview. Canberra: Australian Institute of Criminology, 2004.

[19] BROGDEN, M., NIJHAR, P.: Community Policing. National and International Models and Approaches. Culmcott: Willan Publishing, 2005. 